\title{
Short communication: Influence of various proteolytic sources during fermentation of reconstituted corn grain silages
}

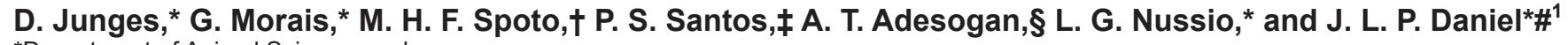 \\ *Department of Animal Science, and \\ †Department of Agri-food Industry, Food and Nutrition, University of São Paulo, Luiz de Queiroz College of Agriculture, Piracicaba, Brazil, \\ 13418900 \\ ¥Nuclear and Energetic Research Institute, São Paulo, Brazil, 05508-000 \\ §Department of Animal Sciences, Institute of Food and Agricultural Sciences, University of Florida, Gainesville 32611 \\ \#Department of Animal Science, State University of Maringá, Maringá, Brazil, 87020900
}

\begin{abstract}
The objective of this study was to determine the contribution of corn kernel enzymes, bacteria, fungi, and fermentation end-products (main acids and ethanol) to protein solubilization during fermentation of reconstituted corn grain silage. Flint corn kernels were ground (5-mm sieve), rehydrated to $32 \%$ of moisture, and treated with no additives (control), gamma irradiation (32 kGy), gamma irradiation + fermentation end-products ( $1 \%$ of lactic acid, $0.3 \%$ of acetic acid, and $0.7 \%$ of ethanol, as fed), and natamycin (1\% as fed). Treated grains were ensiled in nylon-polyethylene bags and stored for $90 \mathrm{~d}$. Protein solubilization was calculated for each treatment and the contributions of proteolytic sources were determined. Bacterial activity was the main contributor to proteolysis $(60 \%)$ followed by corn kernel enzymes (30\%), whereas fungi and fermentation end-products had only minor contributions ( $\sim 5 \%$ each).
\end{abstract}

Key words: fermentation, prolamin, protein matrix, starch digestibility

\section{Short Communication}

The starch-protein matrix in corn kernels is a physicochemical impairment to starch digestion in ruminants (Owens et al., 1986). Ensiling corn grain with high moisture content causes degradation of endosperm hydrophobic proteins during the fermentation process (Thornton, 1976; Baron et al., 1986). Several mechanisms are involved in the breakdown of proteins in whole-crop silages, such as plant enzyme-mediated as well as microbial and acid-induced proteolysis (Ohshima and McDonald, 1978; Heron et al., 1986). In corn grain silages, protein degradation can be due to kernel

Received March 27, 2017.

Accepted May 2, 2017.

${ }^{1}$ Corresponding author: jlpdaniel@uem.br proteases (Simpson, 2001), microorganisms (Baron et al., 1986), and fermentation acid solubilization (Lawton, 2002), but the relative contribution of these agents to total proteolysis is unknown.

It has been claimed that fermentation acids play a major role in solubilizing the proteinaceous matrix surrounding corn starch granules and increasing starch digestibility (Prigge et al., 1976; Philippeau and Michalet-Doreau, 1998). However, substantial changes in acid load have not been associated with breakdown of zein proteins during fermentation of corn grain silage (Hoffman et al., 2011; Ferraretto et al., 2015). This suggests that the starch-protein matrix in corn kernels is more likely degraded by microbial activity rather than by simple solubilization by fermentation end-products, particularly acids. Research is needed to quantify the relative roles of these different agents of proteolysis in corn kernels to develop effective strategies for increasing protein degradation and optimizing starch digestibility.

The objective of our study was to estimate the relative contribution of corn kernel enzymes, bacteria, fungi, and fermentation end-products to protein solubilization during fermentation of reconstituted corn grain silages. As bacteria are the main microbial population in silages (Pahlow et al., 2003), we hypothesized that bacterial proteolytic activity would be responsible for most of the protein solubilization in corn grain silage, whereas fungi, fermentation end-products, and kernel enzymes could contribute to a lesser extent.

Corn kernels $(\sim 15 \mathrm{~kg})$ with flint endosperm $(79.2 \%$ of vitreousness determined by manual dissection; Dombrink-Kurtzman and Bietz, 1993) were ground using a hammer mill with a 5-mm screen (ML 75-B, Lucato, Limeira, Brazil), rehydrated with distilled water to achieve a moisture content of $32 \%$, and manually split into 4 equal piles. Pile 1 was not treated (control; CON); pile 2 was treated with natamycin (1\% as fed; Natamax, Danisco, Copenhagen, Denmark; NAT) to inhibit fungal metabolism (te Welscher et al., 2008); pile 3 was treated with a solution containing a mix- 
ture of fermentation end-products to supply the main compounds formed during fermentation in corn grain silages, based on available literature (Morais et al., $2017)$ and previous experiments in our laboratory $(1 \%$ of lactic acid, $0.3 \%$ of acetic acid and $0.7 \%$ of ethanol, as fed basis; $99 \%$ purity, Merck, Darmstadt, Germany); and pile 4 was left untreated. The natamycin and fermentation end-products were diluted in the distilled water used to rehydrate the ground kernels right before the reconstitution. Subsequently, grains from each pile were placed into each of 6 nylon-polyethylene bags (22 $\times 35 \mathrm{~cm}, 0.18 \mathrm{~mm}$ thick; Intervac, São Paulo, Brazil) and filled bags (500 g, as fed) were heat-sealed using a vacuum sealer (Jet25; Jetvac, São Caetano do Sul, Brazil). All 6 of the untreated bags from pile 4 were irradiated with $32 \mathrm{kGy}$ of ${ }^{60} \mathrm{Co}$ gamma radiation for $4 \mathrm{~h}$ (IRR) at the Nuclear and Energetic Research Institute (São Paulo, Brazil). All 6 of the bags treated with the fermentation end-products from pile 3 were similarly irradiated (IRR+FEP). The irradiation dose was chosen because in previous reports it curtailed fermentation without adversely affecting plant enzyme activities and chemical composition (Woolford, 1983; Heron et al., 1986). All bags from the 4 treatments (CON, NAT, IRR, and IRR+FEP) were stored at room temperature $\left(24 \pm 3^{\circ} \mathrm{C}\right)$ for $90 \mathrm{~d}$. Three samples of unfermented grains were frozen at $-20^{\circ} \mathrm{C}$ for subsequent analysis.

Subsamples of unfermented grains and grain silages were dried at $60^{\circ} \mathrm{C}$ for $48 \mathrm{~h}$, ground through a 1-mm screen using a Wiley-type mill (MA-680, Marconi, Piracicaba, Brazil) and analyzed for DM (AOAC, 1990), CP (AOAC, 1990), and soluble protein (Krishnamoorthy et al., 1982). Silage extracts were prepared by mixing 25 $\mathrm{g}$ of silage with $225 \mathrm{~mL}$ of distilled water in a stomacher for 4 min (\#130/1, Nova Ética, Vargem Grande Paulista, Brazil). The solution was filtered through 2 layers of sterile cheesecloth, serially diluted in peptone water $\left(10^{-2}\right.$ to $\left.10^{-6}\right)$, and pour-plated in agar plates for microbial counts. De Man, Rogosa, and Sharpe agar (MRS 7543A, Acumedia, Lansing, MI) supplemented with natamycin $(0.25 \mathrm{~g} / \mathrm{L})$ was used for enumeration of lactic acid bacteria (incubation at $30^{\circ} \mathrm{C}$ for $2 \mathrm{~d}$ ). Malt extract agar (MEA M137, Himedia, Mumbai, India) acidified with lactic acid $85 \%(3 \mathrm{~mL} / \mathrm{L})$ was used for enumeration of yeasts and molds (incubation at $30^{\circ} \mathrm{C}$ for 2 and $4 \mathrm{~d}$, respectively). Afterward, tubes with serial dilutions were pasteurized $\left(80^{\circ} \mathrm{C}\right.$ for $\left.13 \mathrm{~min}\right)$ and pour-plated in reinforced clostridial agar (RCA M154, Himedia) supplemented with neutral red $(0.05 \mathrm{~g} / \mathrm{L})$ and cycloserine $(0.2 \mathrm{~g} / \mathrm{L})$ for enumeration of clostridia (anaerobic incubation at $37^{\circ} \mathrm{C}$ for $5 \mathrm{~d}$ ).

The $\mathrm{pH}$ of filtered silage extracts was measured using an electrode (DME-CV1, Digimed, São Paulo, Brazil) and an aliquot was centrifuged at 10,000 $\times g$ for $30 \mathrm{~min}$ at $5^{\circ} \mathrm{C}$ for analysis of fermentation end-products. Lactic acid (Pryce, 1969) and $\mathrm{NH}_{3}-\mathrm{N}$ (Chaney and Marback, 1962) were determined by colorimetry. Ethanol and acetic and butyric acids were measured by GC-MS (GCMS QP 2010 plus, Shimadzu, Kyoto, Japan) using a capillary column (Stabilwax, Restek, Bellefonte, PA; $60 \mathrm{~m}, 0.25 \mathrm{~mm}$ i.d., $0.25 \mathrm{~m}$ ).

Soluble protein was as an index of proteolysis rather than $\mathrm{NH}_{3}-\mathrm{N}$ because the latter is an indicator of deamination, rather than proteolysis, and not all the soluble protein is deaminated during fermentation. Therefore, protein solubilization was calculated for each treatment as

[soluble protein after fermentation $(\% \mathrm{CP})$ ]

- [soluble protein before fermentation $(\% \mathrm{CP})]$.

Contributions of proteolytic sources (kernel enzymes, fermentation end-products, fungi, and bacteria) to total proteolysis were calculated as

Kernel enzymes $(\%)=100 \times[($ protein solubilization in IRR silage)/(protein solubilization in CON silage)],

Fermentation end-products $(\%)=$

$100 \times[$ (protein solubilization in IRR + FEP silage

- protein solubilization in IRR silage)/

(protein solubilization in CON silage)],

Fungi $(\%)=100 \times[($ protein solubilization in CON

silage - protein solubilization in NAT silage)/

(protein solubilization in CON silage)], and

$$
\begin{gathered}
\text { Bacteria }(\%)=100-(\text { contributions to total } \\
\text { proteolysis from kernel enzymes } \\
+ \text { fermentation end-products }+ \text { fungi })
\end{gathered}
$$

Silage composition data were analyzed for a completely randomized design using the GLM procedure of SAS (version 9.3, SAS Institute Inc., Cary, NC). Means were compared using the Tukey test $(\alpha=0.05)$.

The unfermented grain contained $8.19 \pm 0.12 \%$ of $\mathrm{CP}(\%$ of DM), $11.6 \pm 0.55 \%$ of soluble protein $(\%$ of $\mathrm{CP}$ ), and $0.27 \pm \%$ of $\mathrm{NH}_{3}-\mathrm{N}(\%$ of $\mathrm{N}$ ) and had a $\mathrm{pH}=6.03 \pm 0.06$. The composition of the corn grain silages is shown in Table 1. The CON and NAT silages had the highest concentrations of soluble protein and $\mathrm{NH}_{3}-\mathrm{N}$, indicating the greatest proteolysis. This was mainly due to microbial activity (Baron et al., 1986; Hoffman et al., 2011), as indicated by the much lower 
concentrations of $\mathrm{NH}_{3}-\mathrm{N}$ and soluble protein in IRR silages in which microbial growth was curtailed, as well as the much higher $\mathrm{pH}$ of the IRR silage versus the CON silage. Kernel proteases also contributed to protein solubilization (Vierstra, 1996; Simpson, 2001) to a moderate extent, as indicated by the magnitude of the soluble protein concentrations of the IRR silage. The fact that $\mathrm{CON}$ silage had similar $\mathrm{NH}_{3}-\mathrm{N}$ and soluble protein concentration to the NAT silage, in which fungal but not bacterial growth was curtailed, coupled with the substantial lower $\mathrm{NH}_{3}-\mathrm{N}$ and soluble protein concentrations of the IRR versus NAT silage, indicate that fungi contributed only a little to total proteolysis. Although acid solubilization is a possible mechanism of protein breakdown (Lawton, 2002), IRR and IRR+FEP silages had similar concentrations of soluble protein. The IRR+FEP had slightly lower $\mathrm{NH}_{3}-\mathrm{N}$ than IRR silage, reflecting the little proteolysis and deamination by FEP likely because of the instantaneous acidification caused by addition of lactic and acetic acids at ensiling (Heron et al., 1986; McDonald et al., 1991). Therefore, as confirmed in Figure 1, bacterial proteolytic activity was the main mechanism of protein degradation in corn grain silages. Kernel enzymes (plant proteases) also contributed significantly to protein breakdown, whereas fungi and fermentation end-products had only minor contributions to proteolysis.

The IRR treatment was highly but not totally effective at preventing microbial activity, as illustrated by very low counts of lactic acid bacteria and trace concentrations of lactic and acetic acids. Therefore, the contribution of bacteria to proteolysis in silages on farms may be slightly higher than shown in this study. As clostridia rather than lactic acid bacteria are the main proteolytic bacteria in silages $(\mathrm{McDonald}$ et

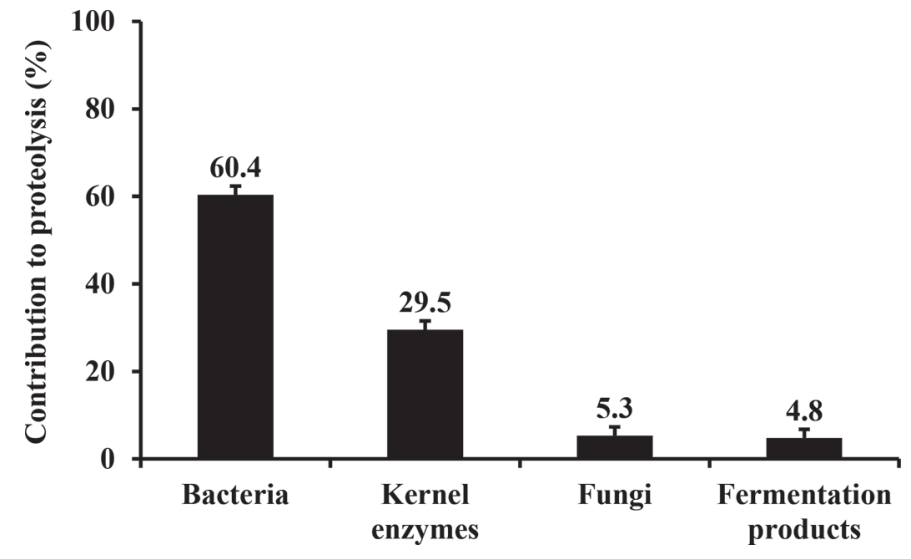

Figure 1. Contribution of corn kernel enzymes, microorganisms (bacteria and fungi), and main fermentation end-products (mixture of lactic acid, acetic acid, and ethanol) to proteolysis in reconstituted corn grain silages. Bars represent the $95 \%$ CI.

al., 1991), exposure to IRR in this study probably prevented the development of clostridium spores and other proteolytic microbes.

Based on the findings that bacteria had the greatest contribution to proteolysis, and the fact that most of the protein in corn kernels is in the matrix surrounding the starch, we deduced that epiphytic and or inoculated bacteria are major determinants of degradation of the protein matrix around starch granules in corn kernels as well as of their starch digestibility. This may be why inoculation of high-moisture corn with Lactobacillus buchneri frequently increases $\mathrm{NH}_{3}$ concentration (Taylor and Kung, 2002; Kung et al., 2007) and, occasionally, starch availability (Revello-Chion et al., 2012; Silva, 2016). As mentioned previously, lactic acid bacteria have low proteolytic activity, but L. buchneri

Table 1. Composition of reconstituted corn grain silages

\begin{tabular}{|c|c|c|c|c|c|c|}
\hline Item & \multicolumn{4}{|c|}{ Treatment $^{1}$} & SEM & $P$-value \\
\hline$\overline{\mathrm{DM}}(\%$ as fed $)$ & 67.0 & 68.0 & 68.3 & 67.5 & 0.58 & 0.11 \\
\hline Soluble protein $(\% \mathrm{CP})$ & $52.3^{\mathrm{a}}$ & $50.1^{\mathrm{a}}$ & $23.6^{\mathrm{b}}$ & $25.5^{\mathrm{b}}$ & 0.61 & $<0.01$ \\
\hline $\mathrm{NH}_{3}-\mathrm{N}(\% \mathrm{~N})$ & $7.36^{\mathrm{a}}$ & $6.99^{\mathrm{a}}$ & $2.60^{\mathrm{b}}$ & $1.65^{\mathrm{c}}$ & 0.21 & $<0.01$ \\
\hline $\mathrm{pH}$ & $3.74^{\mathrm{c}}$ & $3.93^{\mathrm{b}}$ & $5.66^{\mathrm{a}}$ & $3.76^{\mathrm{c}}$ & 0.03 & $<0.01$ \\
\hline Ethanol (\% DM) & $0.56^{\mathrm{b}}$ & $0.04^{\mathrm{c}}$ & $0.03^{\mathrm{c}}$ & $0.91^{\mathrm{a}}$ & 0.03 & $<0.01$ \\
\hline Lactic acid bacteria (log cfu/g) & $5.30^{\mathrm{a}}$ & $4.37^{\mathrm{a}}$ & $2.90^{\mathrm{b}}$ & $2.00^{\mathrm{b}}$ & 0.38 & $<0.01$ \\
\hline Clostridia $(\log \mathrm{cfu} / \mathrm{g})$ & $2.93^{\mathrm{a}}$ & $2.57^{\mathrm{a}}$ & $<2^{\mathrm{b}}$ & $<2^{\mathrm{b}}$ & 0.29 & $<0.01$ \\
\hline Yeast (log cfu/g) & $4.02^{\mathrm{a}}$ & $2.49^{\mathrm{b}}$ & $<2^{\mathrm{c}}$ & $<2^{\mathrm{c}}$ & 0.16 & $<0.01$ \\
\hline Mold (log cfu/g) & $2.39^{\mathrm{a}}$ & $<2^{\mathrm{b}}$ & $<2^{\mathrm{b}}$ & $<2^{\mathrm{b}}$ & 0.12 & $<0.01$ \\
\hline
\end{tabular}

\footnotetext{
${ }^{\mathrm{a}-\mathrm{c}}$ Means within a row with different superscripts differ $(P<0.05)$.

${ }^{1} \mathrm{CON}=$ untreated; NAT $=1 \%$ of natamycin (as-fed basis); IRR $=32 \mathrm{kGy}$ of gamma irradiation; IRR $+\mathrm{FEP}=32 \mathrm{kGy}$ of gamma irradiation +
} $1 \%$ of lactic acid $+0.3 \%$ of acetic acid $+0.7 \%$ of ethanol (as-fed basis). 
may create ecological niches that benefit proteolytic bacteria, perhaps by increasing the $\mathrm{pH}$ due the conversion of lactic acid (a stronger acid) into acetic acid (a weaker acid; Oude Elferink et al., 2001). In addition, the positive correlation between moisture concentration and both proteolysis and starch digestibility in highmoisture corn (Ferraretto et al., 2014) may be due to by modulation of bacterial activity by moisture (Muck, 1988).

Chemical additives (e.g., benzoate, sorbate, and nitrite) are effective at reducing microbial activity and soluble protein and $\mathrm{NH}_{3}-\mathrm{N}$ concentrations in high-moisture corn silage (Da Silva et al., 2015). As soluble protein and $\mathrm{NH}_{3}-\mathrm{N}$ concentrations are positively related to starch digestibility (Ferraretto et al., 2014), high doses of chemical additives that inhibit microbial proteolysis may reduce the disruption of the proteinaceous matrix surrounding starch granules during silage fermentation. Further research is needed to integrate the role of biotic and abiotic factors on proteolysis, starch availability, and ultimately the quality of high-moisture grain silages.

\section{ACKNOWLEDGMENTS}

The authors thank the Fundação de Amparo à Pesquisa do Estado de São Paulo (FAPESP, São Paulo, Brazil), the Conselho Nacional de Desenvolvimento Científico e Tecnológico (CNPq, Brasília, Brazil), and the Coordenação de Aperfeiçoamento de Pessoal de Nível Superior (CAPES, Brasília, Brazil) for the financial support.

\section{REFERENCES}

AOAC. 1990. Official Methods of Analysis. 15th ed. Assoc. Off. Anal. Chem, Arlington, VA.

Baron, V. S., K. R. Stevenson, and J. G. Buchanan-Smith. 1986. Proteolysis and fermentation of grain-corn ensiled at several moisture levels and under several simulated storage methods. Can. J. Anim. Sci. 66:451-461.

Chaney, A. L., and E. P. Marback. 1962. Modified reagents for determination of urea and ammonia. Clin. Chem. 8:130-132.

Da Silva, T. C., M. L. Smith, A. M. Barnard, and L. Kung Jr. 2015. The effect of a chemical additive on the fermentation and aerobic stability of high-moisture corn. J. Dairy Sci. 98:8904-8912.

Dombrink-Kurtzman, M. A., and J. A. Bietz. 1993. Zein composition in hard and soft endosperm of maize. Cereal Chem. 70:105-108.

Ferraretto, L. F., S. M. Fredin, and R. D. Shaver. 2015. Influence of ensiling, exogenous protease addition, and bacterial inoculation on fermentation profile, nitrogen fractions, and ruminal in vitro starch digestibility in rehydrated and high-moisture corn. J. Dairy Sci. 98:7318-7327.

Ferraretto, L. F., K. Taysom, D. Taysom, R. D. Shaver, and P. C. Hoffman. 2014. Relationships between dry matter content, ensiling, ammonia-nitrogen, and ruminal in vitro starch digestibility in high-moisture corn samples. J. Dairy Sci. 97:3221-3227.

Heron, S. J. E., R. A. Edwards, and P. McDonald. 1986. Changes in the nitrogenous components of gamma irradiated and inoculated ensiled ryegrass. J. Sci. Food Agric. 37:979-985.
Hoffman, P. C., N. M. Esser, R. D. Shaver, W. K. Coblentz, M. P. Scott, A. L. Bodnar, R. J. Schmidt, and R. C. Charley. 2011. Influence of ensiling time and inoculation on alteration of the starchprotein matrix in high-moisture corn. J. Dairy Sci. 94:2465-2474.

Krishnamoorthy, U., T. V. Muscato, C. J. Sniffen, and P. J. Van Soest. 1982. Borate-phosphate procedure as detailed in nitrogen fractions in selected feedstuffs. J. Dairy Sci. 65:217-225.

Kung, L., Jr., R. J. Schmidt, T. E. Ebling, and W. Hu. 2007. The effect of Lactobacillus buchneri 40788 on the fermentation and aerobic stability of ground and whole high-moisture corn. J. Dairy Sci. 90:2309-2314.

Lawton, J. W. 2002. Zein: A history of processing and use. Cereal Chem. 79:1-18.

McDonald, P., N. Henderson, and S. Heron. 1991. The Biochemistry of Silage. 2nd ed. Chalcombe Publications, Marlow, UK.

Morais, G., J. L. P. Daniel, C. Kleinshmitt, P. A. Carvalho, J. Fernandes, and L. G. Nussio. 2017. Additives for grain silages: A review. Slovak J. Anim. Sci. 50:42-54.

Muck, R. E. 1988. Factors affecting silage quality and their implications for management. J. Dairy Sci. 71:2992-3002.

Ohshima, M., and P. McDonald. 1978. A review of the changes in nitrogenous compounds of herbage during ensilage. J. Sci. Food Agric. 29:497-505.

Oude Elferink, S. J. W. H., J. Krooneman, J. C. Gottschal, S. F. Spoelstra, F. Faber, and F. Driehuis. 2001. Anaerobic conversion of lactic acid to acetic acid and 1,2-propanediol by Lactobacillus buchneri. Appl. Environ. Microbiol. 67:125-132.

Owens, F. N., R. A. Zinn, and Y. K. Kim. 1986. Limits to starch digestion in the ruminant small intestine. J. Anim. Sci. 63:1634-1648.

Pahlow, G., R. E. Muck, F. Driehuis, S. J. W. H. Oude Elferink, and S. F. Spoelstra. 2003. Microbiology of ensiling. Pages 31-93 in Silage Science and Technology. D. R. Buxton, R. E. Muck, and J. H. Harrison, ed. American Society of Agronomy Inc., Crop Science Society of America Inc., Soil Science Society of America Inc. Publications, Madison, WI.

Philippeau, C., and B. Michalet-Doreau. 1998. Influence of genotype and ensiling of corn grain on in situ degradation of starch in the rumen. J. Dairy Sci. 81:2178-2184.

Prigge, E. C., R. R. Johnson, F. N. Owens, and D. Williams. 1976. Soluble nitrogen and acid production of high moisture corn. J. Anim. Sci. 42:490-496.

Pryce, J. D. 1969. A modification of Barker-Summerson method for determination of lactic acid. Analyst 94:1151-1152.

Revello-Chion, A., G. Borreani, and R. E. Muck. 2012. Effects of various commercial inoculants on the fermentation, aerobic stability and nutritional quality of rolled and ground high moisture corn. Pages 280-281 in Proc. 16th Intl. Silage Conf., Hämeenlinna, Finland. MTT Agrifood Research Finland and University of Helsinki Press, Helsinki, Finland.

Silva, N. C. 2016. Characteristics of corn grain silages influenced by rehydration and inoculation with $L$. buchneri on the performance of feedlot cattle. PhD Diss. Department of Animal Science, The São Paulo State University, Jaboticabal, Brazil.

Simpson, D. J. 2001. Proteolytic degradation of cereal-prolaminsThe problem with proline. Plant Sci. 161:825-838.

Taylor, C. C., and L. Kung Jr. 2002. The effect of Lactobacillus buchneri 40788 on the fermentation and aerobic stability of high moisture corn in laboratory silos. J. Dairy Sci. 85:1526-1532.

te Welscher, Y. M., H. H. Napel, M. M. Balague, C. M. Souza, H. Riezman, B. Kruijff, and E. Breukink. 2008. Natamycin blocks fungal growth by binding specifically to ergosterol without permeabilizing the membrane. J. Biol. Chem. 283:6393-6401.

Thornton, J. H. 1976. Chemical indices of quality of ensiled high moisture corn grain. Pages 150-160 in High Moisture Grains Symposium. Oklahoma State Univ., Stillwater.

Vierstra, R. D. 1996. Proteolysis in plants: Mechanisms and functions. Plant Mol. Biol. 32:275-302.

Woolford, M. K. 1983. Gamma radiation in the preparation of maize silage for studies on the aerobic deterioration process. J. Agric. Sci. 101:711-716. 